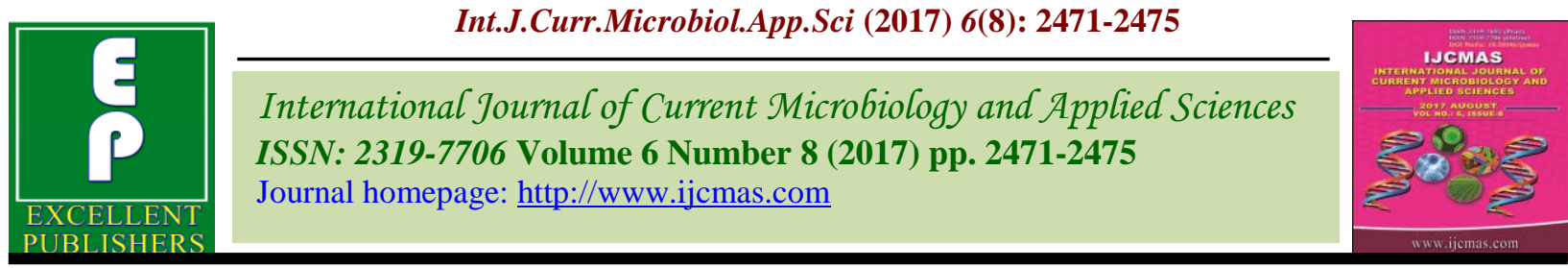

Original Research Article https://doi.org/10.20546/ijcmas.2017.608.292

\title{
Effect of Post Shooting Bunch Spray of Chemicals on Bunch Characters and Yield of Banana (Musa paradisiaca L.) cv. Grand Naine
}

\author{
Rajni Rajan*, S.S. Gaikwad, Mutteppa Gotur, C.J. Joshi and J.K. Chavda \\ Department of Fruit Science, ASPEE College of Horticulture and Forestry, \\ Navsari Agricultural University, Navsari- 396450, Gujarat, India \\ *Corresponding author
}

\begin{tabular}{|l|}
\hline Key w or d s \\
Banana, Bunch, \\
Brassinosteroid, \\
Spray, Chemicals, \\
Yield. \\
\hline Article Info \\
\hline $\begin{array}{l}\text { Accepted: } \\
\text { 21 June } 2017 \\
\text { Available Online: } \\
\text { 10 August } 2017\end{array}$ \\
\hline
\end{tabular}

\section{Introduction}

Banana (Musa paradisiaca L.) is one of the major fruit crop in the tropics and subtropics and make a vital contribution to the economies of a number of countries. It is very important in the nutrition of local population as well as tradable commodities with a large market throughout the developed world. Banana is a large herbaceous perennial monocotyledonous and monocarpic crop. It belongs to the family Musaceae in the order Scitamineae. It is known as "Apple of Paradise". Its origin is the tropical region of South-East Asia. Banana crop has nutritional, medicinal and industrial value and is known for its antiquity and it is interwoven with Indian heritage and culture. Owing to its greater socio-economic significance and multifaceted uses, it is referred as 'Kalpatharu' (plant of virtues).It is a good source of income to the farmers in their respective growing regions (Bridge, 2000; Akinyemi et al., 2010).

Now-a-days, the practice of application of plant growth regulators, chemicals and bunch management treatments are taken for 
improving the growth, maturity, yield and quality of banana fruits are gaining popularity. Plant growth regulators are perhaps the most powerful tool to achieve the goal. These are defined as organic compounds other than nutrients which in small amount promotes/inhibit or modify any physiological response in plants and they are artificially synthesized. PGRs have been successfully used as foliar spray to increase flowering, synchronize bloom or change the time of flowering to avoid the adverse climatic condition or to shift harvest to a time when the market price is more remunerative. PGRs are applied to increase the fruit size directly by stimulating cell division or to increase fruit size and yield.

\section{Materials and Methods}

The present investigation on "Effect of post shooting spray of chemicals on bunch characters and yield of banana (Musa paradisiaca L.)cv. GrandNaine" was carried out at Regional Horticultural Research Station, Navsari Agricultural University, Navsari. Uniform tissue cultured grand naine banana were planted and sprayed twice once at complete opening of inflorescence and other after 20 days of opening. The treatment comprised of the spray of viz., $\mathrm{GA}_{3} @ 50 \mathrm{mg}$ $\mathrm{l}^{-1}\left(\mathrm{~T}_{1}\right), \mathrm{GA}_{3} @ 100 \mathrm{mg} \mathrm{l}^{-1}\left(\mathrm{~T}_{2}\right)$, NAA @ 50 mg $1^{-1}\left(\mathrm{~T}_{3}\right)$, NAA @ $100 \mathrm{mg} \mathrm{l}^{-1}\left(\mathrm{~T}_{4}\right)$, Ethephon@0.1 $\mathrm{ml} \mathrm{l}^{-1}\left(\mathrm{~T}_{5}\right)$, Ethephon@0.2 $\mathrm{ml} \mathrm{l}^{-1}\left(\mathrm{~T}_{6}\right), \mathrm{CPPU} @ 1 \mathrm{mg} \mathrm{l}^{-1}\left(\mathrm{~T}_{7}\right), \mathrm{CPPU} @ 2$ $\mathrm{mg} \mathrm{l}^{-1}\left(\mathrm{~T}_{8}\right)$, Brassinosteroid @ $1 \mathrm{mg} \mathrm{l}^{-1}\left(\mathrm{~T}_{9}\right)$, Brassinosteroid @ $2 \mathrm{mg} \mathrm{l}^{-1}\left(\mathrm{~T}_{10}\right)$, SOP @ $1.5 \%\left(\mathrm{~T}_{11}\right)$ and Control $\left(\mathrm{T}_{12}\right)$ were evaluated in randomly block design with three repetition. The experimental plot was prepared by deep ploughing, harrowing and levelling. The pits of $30 \times 30 \times 30 \mathrm{~cm}$ were dug out at a spacing of $2.4 \times 1.2 \mathrm{~m}^{2}$ and welldecomposed fine textured Farm Yard Manure (FYM) at the rate of $10 \mathrm{~kg}$ per pit was applied at planting. Well hardened, healthy tissue culture plants of Grand Naine banana having
5-6 leaves were used for planting. After full emergence of inflorescence the male bud was removed and sprayed with chemicals first after the complete opening of inflorescence and second 20 days after first spray. Bunches were covered with blue polythene covers of 50 micron in all the treatments immediately after second spray. Observations were recorded daily for bunch and yield characters. Bunch length $(\mathrm{cm})$, Bunch girth $(\mathrm{cm})$, Number of fingers per bunch, Finger length $(\mathrm{cm})$, Finger girth $(\mathrm{cm})$, Finger weight (g),Weight of third hand (kg), Bunch weight $(\mathrm{kg})$, Fruit yield (t/ha) were recorded. Bunch characters were counted from each bunch at the harvest when fruits reached full growth stage and mean was calculated. The data of the yield per net plot was recorded and multiplied by multiple factor computed on area basis to give the final data for total yield in tonnes per hectare. The data recorded during the course of investigation were subjected to statistical analysis following standard procedure described by Panse and Sukhatme (1967).

\section{Results and Discussion}

In present investigation increase bunch size (length and girth in $\mathrm{cm}$ ), finger length $(\mathrm{cm})$ and finger girth $(\mathrm{cm})$ from third hand, finger weight $(\mathrm{g})$ from third hand, weight of third hand $(\mathrm{Kg})$, bunch weight $(\mathrm{Kg})$ and fruit yield (t/ha) was found superior in Brassinosteroid @ $2 \mathrm{mg} \mathrm{l}^{-1}$. The bunch characters related results shows Bunch length was significantly influenced due to the application of different chemicals as bunch spray. Significantly the highest bunch length $(96.28 \mathrm{~cm})$ was noted in treatment $\mathrm{T}_{10}$ (Brassinosteroid @ $2 \mathrm{mg} \mathrm{l}^{-1}$ ). The minimum bunch length $(73.84 \mathrm{~cm})$ was noticed in control $\left(\mathrm{T}_{12}\right)$. The bunch girth was significantly influenced by the different postshooting chemical treatments. Post-shooting bunch spray of Brassinosteroid @ $2 \mathrm{mg} \mathrm{l}^{-1}$ $\left(\mathrm{T}_{10}\right)$ recorded the maximum bunch girth $(128.80 \mathrm{~cm})$. 
Table.1 Effect of post shooting bunch spray of chemicals on bunch characters viz. Bunch length (cm), Bunch girth (cm), Number of fingers per bunch, Finger length $(\mathrm{cm})$, Finger girth $(\mathrm{cm})$, Finger weight $(\mathrm{g})$ of banana cv. Grand Naine

\begin{tabular}{|c|c|c|c|c|c|c|}
\hline Treatments & $\begin{array}{c}\text { Bunch length } \\
(\mathrm{cm})\end{array}$ & $\begin{array}{l}\text { Bunch girth } \\
\text { (cm) }\end{array}$ & $\begin{array}{c}\text { Number of fingers per } \\
\text { bunch }\end{array}$ & $\begin{array}{c}\text { Finger length } \\
(\mathrm{cm})\end{array}$ & $\begin{array}{c}\text { Finger girth } \\
(\mathbf{c m})\end{array}$ & Finger weight (g) \\
\hline T1-GA3@50 mg l ${ }^{-1}$ & 90.94 & 119.93 & 166.43 & 23.54 & 13.57 & 191.93 \\
\hline T2-GA3@100 $\mathrm{mg} \mathrm{l}^{-1}$ & 92.49 & 121.47 & 169.37 & 23.72 & 13.64 & 208.58 \\
\hline T3 - NAA @ $50 \mathrm{mg} \mathrm{l}^{-1}$ & 78.57 & 113.87 & 172.11 & 20.25 & 12.57 & 150.37 \\
\hline T4 - NAA @100 mg l-1 & 81.46 & 113.47 & 175.63 & 21.67 & 12.12 & 174.07 \\
\hline T5 - Ethephon @ $0.1 \mathrm{ml} \mathrm{l}^{-1}$ & 75.50 & 90.73 & 168.67 & 18.82 & 12.15 & 144.27 \\
\hline T6 - Ethephon @ $0.2 \mathrm{ml} \mathrm{l}^{-1}$ & 76.23 & 110.93 & 165.23 & 19.25 & 12.30 & 145.87 \\
\hline T7-CPPU @1.0 mg l-1 & 86.88 & 111.33 & 168.36 & 22.60 & 13.57 & 188.99 \\
\hline T8-CPPU @ $2.0 \mathrm{mg} \mathrm{l}^{-1}$ & 87.18 & 105.33 & 166.68 & 22.15 & 13.30 & 144.27 \\
\hline T9 - Brassinosteroid @ $1.0 \mathrm{mg} \mathrm{l}^{-1}$ & 94.84 & 124.33 & 166.21 & 24.15 & 14.53 & 216.69 \\
\hline T10-Brassinosteroid @ $2.0 \mathrm{mg} \mathrm{l}^{-1}$ & 96.28 & 128.53 & 162.22 & 24.50 & 15.85 & 225.65 \\
\hline T11-SOP@ @ 1.5\% & 85.36 & 109.87 & 157.30 & 23.03 & 13.57 & 171.15 \\
\hline T12 - Control & 73.84 & 106.00 & 158.47 & 18.61 & 11.06 & 131.73 \\
\hline S.Em. \pm & 4.91 & 5.83 & 3.98 & 1.34 & 0.59 & 10.33 \\
\hline C.D. at $5 \%$ & 14.41 & 17.10 & NS & 3.92 & 1.74 & 30.29 \\
\hline $\mathrm{CV} \%$ & 10.01 & 8.94 & 4.15 & 10.60 & 7.79 & 10.25 \\
\hline
\end{tabular}

Table.2 Effect of post shooting bunch spray of chemicals on yield characters viz. weight of third hand (kg), Bunch weight (kg), Fruit yield (t/ha) of banana cv. Grand Naine

\begin{tabular}{|c|c|c|c|}
\hline Treatments & Weight of third hand (kg) & Bunch weight (kg) & Fruit yield (t/ha) \\
\hline T1-GA3@50 mg l ${ }^{-1}$ & 2.90 & 28.08 & 97.51 \\
\hline T2-GA3@100 mg l ${ }^{-1}$ & 3.35 & 29.37 & 101.98 \\
\hline T3 - NAA@ @ $50 \mathrm{mg} \mathrm{l}^{-1}$ & 2.23 & 25.28 & 87.79 \\
\hline T4 - NAA@100 mg l-1 & 2.31 & 25.37 & 87.72 \\
\hline T5 - Ethephon@0.1 ml 1 ${ }^{-1}$ & 2.18 & 24.38 & 84.64 \\
\hline T6 - Ethephon @ $0.2 \mathrm{ml} \mathrm{l}^{-1}$ & 2.22 & 25.21 & 87.52 \\
\hline T7 - CPPU @ $1.0 \mathrm{mg} \mathrm{l}^{-1}$ & 2.41 & 26.69 & 92.66 \\
\hline T8-CPPU@2.0 mg l-1 & 2.69 & 26.99 & 93.70 \\
\hline T9 - Brassinosteroid @ $1.0 \mathrm{mg} \mathrm{l}^{-1}$ & 3.39 & 30.35 & 105.37 \\
\hline T10- Brassinosteroid @ $2.0 \mathrm{mg} \mathrm{l}^{-1}$ & 4.01 & 32.96 & 114.46 \\
\hline T11-SOP @ 1.5\% & 2.33 & 27.95 & 97.05 \\
\hline T12 - Control & 2.06 & 24.26 & 84.24 \\
\hline S.Em. \pm & 0.15 & 1.31 & 4.56 \\
\hline C.D. at $5 \%$ & 0.44 & 3.85 & 13.36 \\
\hline CV\% & 9.68 & 8.35 & 8.35 \\
\hline
\end{tabular}


The minimum bunch girth $(90.73 \mathrm{~cm})$ was recorded in Ethephon@ $0.1 \mathrm{ml} \mathrm{l}^{-1}\left(\mathrm{~T}_{5}\right)$.Increase in length and girth of bunch may be also due to BR has growth promoting effects similar to auxin and gibberellins and found to have promising effects on cell elongation by increasing the cell permeability to water and osmotic solutes of the cells. It might be possible that spray of BRs concentrations increased sensitivity of auxin (Zhang et al., 2009).

Besides, auxins like characters of BRs are also responsible for inducing the synthesis of specific DNA dependent new m-RNA and specific enzymatic proteins causes increased cell plasticity and extension resulting ultimately in cell enlargement. Similar results were revealed by Champa et al., (2015) in grapes and Cha Fang et al., (2004) in orange.

In the present investigation, number of fingers was found to be non-significant due to chemicals. The probable reason could be that the plant regulators were applied after complete opening of inflorescence, whereas, the number of hands and fingers were already fixed at initiation of inflorescence from underground stem long before. The findings are supported with those of Parmar (1984) and Gandhi (1984).

The post-shooting bunch spray of chemical treatments had significant effect on the finger length from third hand. Significantly the longest finger from third hand $(24.50 \mathrm{~cm})$ was observed under $\mathrm{T}_{10} \quad$ (Brassinosteroid @ $2 \mathrm{mg} \mathrm{l}^{-1}$ ) treatment. The shortest finger length from third hand $(18.61 \mathrm{~cm})$ was recorded in control $\left(\mathrm{T}_{12}\right)$.

Significantly the highest finger girth from third hand $(15.85 \mathrm{~cm})$ was recorded in $\mathrm{T}_{10}$ (Brassinosteroid@2 mg $\mathrm{l}^{-1}$ ) treatment. The minimum finger girth from third hand (11.06 $\mathrm{cm})$ was recorded in control $\left(\mathrm{T}_{12}\right)$. Brassinosteroid influence the finger characters by inducing cell division, elongation and differentiation (Ge Cheng et al., 2004) has. In addition, brassinosteroid stimulate the accumulation of photosynthates through increase carbohydrate assimilation and enhanced mobilization of metabolites to the fruits (Fujioka, 1997). The findings in the present study are in consonance with the findings of (Bhat et al., 2011) in grape and Gomes et al., (2006) in yellow passion fruit.

It is apparent from the data that weight of third hand was significantly influenced due to applications of different chemicals. Significantly the maximum weight of third hand $(4.01 \mathrm{Kg})$ was noted in Brassinosteroid @ 2 mg $\mathrm{l}^{-1}$ treatment $\left(\mathrm{T}_{10}\right)$.

The minimum weight of third hand $(2.06 \mathrm{Kg})$ was noticed in control $\left(\mathrm{T}_{12}\right)$. Also the postshooting bunch spray of Brassinosteroid @2 $\mathrm{mg}^{-1}\left(\mathrm{~T}_{10}\right)$ resulted in maximum bunch weight $(32.96 \mathrm{~kg})$ and fruit yield (114.46 t/ha). The minimum bunch weight $(24.26 \mathrm{~kg})$ and fruit yield $(82.24 \mathrm{t} / \mathrm{ha})$ were registered in control (T12) (Tables 1 and 2).

Brassinosteroid @ 2 ppm improved the yield by regulating the function in cell elongation and cell division (Clouse and Sasse, 1998). It induces cell division, elongation and differentiation and stimulates photosynthetic activity by accelerating $\mathrm{CO}_{2}$ fixation and further increasing protein biosynthesis. Besides, BR is known to promote nucleic acid level, nitrogen fixation and enhance soluble protein content and increase in DNA and RNA concentrations.

Apart from these physiological responses, Brassinosteroids has growth promoting effects similar to auxin and gibberellins and found to have promising effects on total yield improvement (Vardhini and Rao, 1998). Similar results were revealed by Mulagund et al., (2015) in banana, Sugiyama and Kuraishi (1989) and Cha Fang et al., (2004) in orange, Champa et al., (2015) and Bhat et al., (2011) in grapes and Gomes et al., (2006) in yellow passion fruit.

\section{References}

Akinyemi, S.O.S., Staver, C., Ayelaagbe, I.O.O., Kintomo, A.A. and Babalola, S.O. 
2010. Perspectives of small-scale Musa processing firms in Nigeria, Acta Horticulturae, 879: 263-287.

Bhat, Z. A., Reddy, Y. N. and Srihari, D. 2011. New generation growth regulators Brassinosteroids and CPPU improve bunch and berry characteristics in 'Tas-AGanesh' grape. International J. Fruit Science. 11: 309-315.

Bridge, J. 2000. Nematodes of bananas and plantain in Africa: Research trends and management strategies relating to the small-scale farmer, Acta Horticulturae, 540.

Champa H.W.A., Gill M.I.S., Mahajan B.V.C., Aror N.K. and SeemaBedi 2015.Brassinosteroids improve quality of table grapes (Vitis vinifera L.) cv. Flame Seedless. Tropical Agricultural Research, 26 (2): $368-379$.

ChangFang, W., YongFeng, C., XueSong, Lu. Jun, W. and Jinshi, W. 2004. Adjusting effect of brassinolide and GA4 on the orange growth. Acta Agril Jiangxiensis., 26 (5): 759-762.

Clouse, S. D. and Sasse, J. M. 1998. Brassinosteroids; Essential regulators of plant growth and development. Аnnu. Rev. Plantphysiol. 49: 427-451.

Fujioka, S. S. A. 1997. Biosynthesis and metabolism of brassinosteroids. Physiologia Plantarum. 100: 710-715.

Gandhi, V. P. 1984. Effect of certain plant regulators, Urea and sleeving on maturity and quality of banana cv. Basrai. M.Sc. (Agri.) Thesis in Horticulture Gujarat Agricultural University, S.K Nagar, Gujarat.
GeCheng, Z., YuWin, Q., QuanZhou, He. And CaiLu, T. 1999. Effect of spraying brassinolide on the production and fruit quality of litchi. South China Fruits. 28(2): 35 .

Gomes M. M. A.; Campostrini E.; Rocha N.; Viana L.A.P. 2006.Brassinosteroid analogue effects on the yield of yellow passion fruit plants (Passiflora edulis $f$. flavicarpa). Sci. Hort. 110: 235-240.

Mulagund, J., Kumar, S., Soorinathasundaram, K. and Porika, H. 2015. Influence of postshooting sprays of Brassinosteroid on bunch characters and fruit yield of banana cv. Nendran. The Bioscan, 10 (1): 153159.

Panse, V. C. and Sukhatme, P. V. 1967.Statistical Methods for Agricultural Workers, ICAR, New Delhi.

Parmar, B.R. and Chundawat, B.S. 1984. Effect of growth regulators and sleeving on maturity and quality of banana cv. Basari. South Indian Hort., 32 (4): 201-204.

Sugiyama, K. and Kuraishi, S. 1989.Stimulation of fruit set of 'Morita' navel orange with brassinolide. VI International Symposium on Growth Regulators in Fruit Production. Acta Horticulturae, 239: 345348.

Vardhini, B., Vidya and Rao, S.R. 1998. Effect of brassinosteroids on germination of groundnut (Arachis hypogaea L.) seeds. Indian J. PlantPhysiol. 1 (3):223-224.

Zhang, S., Wei, Y., Lu, Y. and Wang, X. 2009. Mechanisms of brassinosteroids interacting with multiple hormones. Plant Signal Behav, 4: 1117-1120

\section{How to cite this article:}

Rajni Rajan, S.S. Gaikwad, Mutteppa Gotur, C.J. Joshi and Chavda, J.K. 2017. Effect of Post Shooting Bunch Spray of Chemicals on Bunch Characters and Yield of Banana (Musa paradisiaca L.) cv. Grand Naine. Int.J.Curr.Microbiol.App.Sci. 6(8): 2471-2475. doi: https://doi.org/10.20546/ijcmas.2017.608.292 